\title{
A SZABAD FRANCIA LÉGIERŐ TEVÉKENYSÉCE AFRIKÁBAN
}

\section{BENE KRISZTIÁN}

Miközben a második világháború vitathatatlanul a (had)történelem legjobban kutatott fejezetei közé tartozik, egyes részletei mindmáig nem kerültek a tudományos és olvasói érdeklődés homlokterébe. Ez utóbbiak közé tartozik a Szabad Francia Légierő tevékenysége a konfliktus során, amelyről a mai napig nem született érdemi összefoglalás, ebből kifolyólag az afrikai hadszíntéren nyújtott teljesítménye is kevéssé vált ismertté.

Jelen tanulmány azt a célt tüzte ki maga elé, hogy a rendelkezésre álló terjedelmi keretek szabta korlátokon belül bemutassa a Charles de Gaulle tábornok irányítása alatt álló légierő megszületését, majd a különböző afrikai hadszíntereken történő bevetését 1940 és 1943 között. Reményeink szerint ez a hadtörténeti hiánypótlás hozzájárul mind a szabad franciák háborús erőfeszítéseinek, mind pedig az afrikai kontinensen zajló világháborús összecsapások egyes részleteinek jobb megismeréséhez.

\section{Nehéz kezdetek}

Az 1940 májusában-júniusában elszenvedett gyors és teljesen váratlan vereség megsemmisítő hatással volt a francia fegyveres erőkre. A szárazföldi erök egy része felmorzsolódott a harcok folyamán, közel kétmillióan pedig fogságba kerültek. Ezzel párhuzamosan a légierő is kivette részét a harcokból, melyek során a rendelkezésre álló források alapján a légvédelmi fegyverekkel együtt hozzávetőlegesen 8-900 német gépet semmisített meg, miközben hasonló számú gépet veszített el, ami a bevethető eszközállományának körülbelül felét tette ki. Harci értéke tehát még számottevő volt a harcok befejezésekor, azonban egyértelmủ utasítások híján a repülőszemélyzet és a gépállomány sorsa meglehetősen változatosan alakult. Sokan feletteseik parancsait követve állomáshelyükön várták be a német csapatokat, mások a harc folytatásában bízva az észak-afrikai francia területekre repültek, de akadtak olyanok is, akik a közelebbi Angliát választották, ahová légi vagy tengeri úton jutottak el. ${ }^{1}$

Utóbbiak nem egységes felsőbb utasításra cselekedtek, legtöbbjük esetében csupán a harc folytatásának vágya motiválta az ország elhagyását, egyesek pedig a június 18-i felhívás hatására választották a gyakran veszélyes utat a Brit Birodalom különböző területei felé a Brit-szigetektől kezdve Gibraltáron és Máltán át 
Szingapúrig. Az esetek többségében a francia légierő tagjai egyénileg vagy kisebb csoportokban kíséreltek meg eljutni brit területre, melynek eszköze számos esetben természetesen az általuk használt repülőgép volt. Ugyanakkor sokan - megfelelö gép hiányában - a tengeri utat választották, amikor hazai és külföldi felségjelzésü civil és katonai jármüvekre felkéredzkedve próbálták céljukat elérni. ${ }^{2}$ A legnagyobb csoportos átkelésre június 17-én - tehát még De Gaulle beszéde előtt - került sor, amikor a 23-as számú repülöiskola 108 pilótanövendéke egy halászhajó fedélzetén áthajózott Nagy-Britanniába a La Manche csatornán keresztül. ${ }^{3}$ Az első ilyen akcióra 1940. június közepén, az utolsóra 1941 áprilisában került sor, amelyek során valamivel több mint 500 repülős (pilóta, müszaki és repülőszemélyzet) csatlakozott a szövetséges haderőhöz, amely lehetővé tette 1940. július 1-én a Szabad Francia Légierő létrehozását. A rendelkezésre álló személyzet önállóan bevethető alakulatokba szervezését jelentős mértékben akadályozta a müszaki állomány alacsony aránya a jelentkezők között, ${ }^{4}$ valamint a magasabb beosztású tisztek és a nem pilótaként szolgáló repülőszemélyzet (navigátorok, rádiósok, lövészek stb.) gyakorlatilag teljes hiánya. ${ }^{5}$ Utóbbi tény magyarázza azt is, hogy bár átmeneti jelleggel, de a szabad francia repülő erőket Émile Muselier admirális irányítása alá rendelték, mivel nem állt rendelkezésre más szabad francia fötiszt, aki ezt a posztot betölthette volna. ${ }^{6}$

Ez a meglehetősen zürzavaros helyzet is hozzájárult ahhoz, hogy a harcokban részt venni kívánó pilóták egy része 1940 nyarán nem a Szabad Francia Légierő soraiba jelentkezett, hanem közvetlenül a Brit Királyi Légierőt (RAF) választotta, amely lehetővé tette számukra, hogy rövid átképzés után brit alakulatok kötelékébe beosztva már a Nagy-Britanniát támadó német gépek ellen küzdjenek. Az ö számuk 140 főre tehető és nyolc különböző brit repülőszázad állományába szétosztva kerültek bevetésre a későbbiekben. ${ }^{7}$ Ugyanakkor a kiképzett pilóták alacsony száma $(14 \text { fó })^{8}$ miatt csupán 12 fó vett részt már az angliai csata során harci bevetéseken, a többieket típusátképzésre irányították a brit hatóságok, illetve földi szolgálatot teljesítettek. ${ }^{9}$

A szabad francia vezetés mindent megtett annak érdekében, hogy ezt a szerény részvételt a lehető leghamarabb magasabb szintre emelje, ugyanakkor pedig a brit területek védelmében már harci tapasztalatot szerző és az átképzésen átesett pilótákat pedig saját alakulatok kötelékében vonja össze. Előbbiek száma csupán 11 fő volt, utóbbiaké viszont 170, így hosszú időre volt szükség ahhoz, hogy a megfelelő számú és minőségü személyzet rendelkezésre álljon az új egység felállításához. Ezzel egyidőben hosszas egyeztető tárgyalásokat folytattak a RAF parancsnokságával, amely azzal a feltétellel adta áldását a tervre, hogy az új alakulat brit irányítás alatt kerül majd bevetésre, amit szabad francia részről is elfogadtak. ${ }^{10}$ Ugyanakkor a RAF kötelékében harcoló francia pilóták számára nem volt kötelezö átlépni a kialakítandó szabad francia egységek valamelyikében, így voltak köztük olyanok, akik a háború végéig brit egységekben harcoltak. ${ }^{11}$ A 340. repülőcsoportot hivatalosan végül csupán 1941. november 7-én Turnhouse-ban hozták létre, mint a brit 13. repülőosztag egyik alegységét és az ekkoriban igen modernnek számító Spitfire I és IIa vadászgépekkel $^{12}$ szerelték fel. A század megbízott parancsnoka (Keith Temple Lofts hadnagy) 
és a technikai személyzet is angol volt, de azzal a kitétellel, hogy amint megfelelöen kiképzett és tapasztalt állományt sikerül kinevelni, franciák fogják felváltani öket. ${ }^{13}$ Miután november 29-én bevethetőnek nyilvánították, az egységet áthelyezték DélAngliába, ahol a következő hónapok során légtérvédelmi feladatokat látott el, majd 1942 márciusától - immár francia parancsnok vezetésével és 18 darab Spitfire $\mathrm{Vb}$ géppel teljes létszámra feltöltve ${ }^{14}$ - részt vett a RAF Nyugat-Európa (és elsősorban a megszállt Franciaország) fölé vezetett nagyszabású akcióiban, melyek elsődleges célja a német vadászgép-állomány felörlése volt. ${ }^{15}$

\section{Az első afrikai bevetések}

Ezzel párhuzamosan De Gaulle kiemelt fontosságúnak tartotta olyan légi egységek létrehozását, melyek nincsenek alárendelve a brit katonai vezetésnek, így a szabad francia célok érdekében szabadon be lehet vetni őket. Noha a rendelkezésre álló személyi és anyagi eszközök meglehetősen szerények voltak - különös tekintettel arra, hogy Nagy-Britannia saját védelmének biztosítása érdekében mozgósított minden elérhető erőforrást -, mégis sikerült 1940. augusztus 1-én felállítani az úgynevezett 1. (légi) harccsoportot Lionel de Marmier örnagy parancsnoksága alatt. A meglehetősen furcsa összetételü alakulat négy félszázadból állt, melyek között egy vadász- (két géppel), egy bombázó- (hat géppel) és két felderítőegység (12 géppel) volt összesen 160 fös személyzettel. ${ }^{16}$ A félhivatalosan Jam névre hallgató alakulat gépeit a Dakar elfoglalását célzó hadmüvelet támogatására szánták, ezért augusztus végén a gépeket szétszerelve hajóra rakodták és útnak indították Nyugat-Afrika felé. ${ }^{17}$ A sikertelen akció után az egységet novemberben Gabon elfoglalása során a szárazföldi támadóoszlopok támogatására vetették be, ${ }^{18}$ mielőtt december 10 -én feloszlatták. ${ }^{19}$

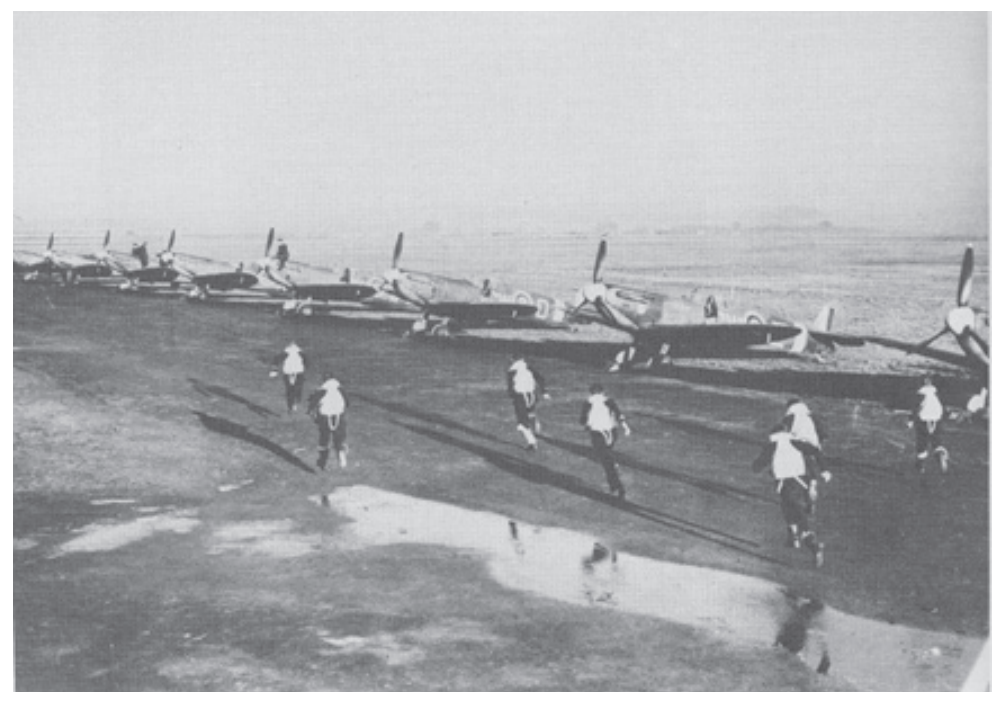

$\bigwedge$ A 340. (késöbb Île-de-France) repülöcsoport ${ }^{20}$ 
Szintén augusztus folyamán állították fel Angliában Jean Astier de Villatte százados vezetésével a Topic elnevezésü félszázadot, melyben 8 rossz állapotban lévő, erősen elhasználódott Bristol Blenheim bombázó ${ }^{21}$ és 44 főnyi személyzet teljesített szolgálatot. Az egységet októberben átirányították Csádba, ahol a frissen csatlakozott szabad francia területek védelmét kellett elösegíteniük az esetleges olasz vagy Vichy-francia támadások ellen. Ennek a feladatnak a keretében a Topic és a Jam bombázógépeit összevonták egy új egység keretében, így december 24-től ezek alkották az 1. bombázócsoportot, mely összesen 14 bevethető repülővel rendelkezett. ${ }^{22}$ Az alakulat aktívan támogatta Leclerc ezredesnek a Kufra oázis ellen indított támadó hadmüveletét, mivel felderítő és bombázó repüléseket is végrehajtottak a szárazföldi akció megindítása előtt. Míg a felderítés során készített felvételek nagyon hasznosnak bizonyultak, a bombázótámadások gyakorlatilag teljesen eredménytelenek voltak, ráadásul saját veszteségekkel is jártak, mivel két gépnek is kényszerleszállást kellett végrehajtania technikai problémák, illetve üzemanyaghiány miatt, négy másik pedig hosszabb időre használhatatlanná vált az elszenvedett sérülések miatt, ${ }^{23}$ miközben a személyi állományból 5 fö meghalt vagy eltünt, 3 megsebesült, 3 pedig fogságba esett. ${ }^{24}$ Leclerc ezredes megállapítása szerint ennek a sikertelenségnek az okait a különösen nehéz terepadottságokban (és elsősorban a minden gépet megviselö homokban), a célnak kevéssé megfelelő repülőkben és a gyengén kiképzett repülőszemélyzetben kellett keresni. ${ }^{25}$ Mindemellett a sikeres hadmüveletben játszott fontos szerepéért az alakulatot hadseregparancsban tüntették ki, ami komoly elismerést jelentett. ${ }^{26}$

A hiányosságok ellenére is nagy szükség volt az afrikai hadszíntéren minden bevethető harci repülőre, ezért az egységet a délkelet-líbiai Kufra elfoglalása után 1941 márciusában átirányították Kelet-Afrikába, hogy légi támogatást nyújtson az Etiópiában küzdő szövetséges csapatoknak. A gépek müszaki állapotát jól jellemzi az a tény, hogy az áttelepülésre kijelölt hat repülőből végül csak hármat találtak repülésre alkalmasnak, de az is jelentős időt vett igénybe, hogy ezeket felkészítsék a hosszú repülőútra. A három gépet a Kartúmban állomásozó 203. brit repülőcsoporthoz csatolták, amelynek kötelékében március 24-től vettek részt harci bevetéseken.$^{27} \mathrm{Az}$ alakulat harcértékét növelendő a brit parancsnokság április elején hat repülőgépet irányított át a szabad franciákhoz, ami lehetővé tette, hogy az addig Csádban állomásozó személyi állomány is csatlakozzon a kelet-afrikai régióban harcoló különítményhez és részt vegyen a bevetéseken. ${ }^{28}$ Az augusztus közepéig tartó időszakban a folyamatosan müszaki problémákkal küszködő egység 180 bevetést hajtott végre, melyek során 40 tonna bombát és 25.000 töltényt használtak fel, miközben egy ellenséges repülőgépet is megsemmisítettek. A teljesítményt a szabad francia vezetés újabb kitüntetéssel jutalmazta. Bár a hadmúveletek során egyetlen gépet sem veszítettek, kettő megsemmisült gyakorlórepülések során, számos másik pedig müszaki okokból vált használhatatlanná, így összesen csupán három müködőképes repülőjük maradt. De Gaulle utasítása értelmében augusztus 13-án a bombázócsoportot Damaszkuszba helyezték át, ${ }^{29}$ ahol a harcedzett személyi állomány és a rendelkezésre álló gépek felhasználásával szeptember 2-án létrehoz- 
ták a két félszázadból álló Lotaringia bombázócsoportot ${ }^{30}$ amely felállítása után hozzávetőlegesen 20 Blenheim bombázóval rendelkezett, ${ }^{31}$ amelyek nagy részét a brit hatóságok bocsátottak a rendelkezésükre. ${ }^{32}$

A francia kormány jelentős számban rendelt amerikai gyártású harci repülöket, köztük Glenn Martin 167 bombázókat, ${ }^{33}$ melyek egy részét a fegyverszünet megkötése miatt nem szállították le számára. Ezeket az amerikai fél Nagy-Britannia számára adta át, amely szabad francia kérésre beleegyezett, hogy nyolc repülővel az 1941 márciusában Brazzaville-ben felállított 2. szabad francia bombázócsoportot szereljék fel. ${ }^{34} \mathrm{Az}$ alakulatot májusban Egyiptomba helyezték át, ahol a 24. dél-afrikai, majd a 223. brit bombázószázad kötelékében teljesített szolgálatot. A legénység tapasztalatlansága miatt az egység eleinte kiképzési és felderítő feladatokat hajtott végre, ${ }^{35}$ majd a nyár folyamán néhány harci bevetésre is beosztották Szíria és Kréta felett, melyek során egy gépet elvesztettek. ${ }^{36}$ Szeptember elején az állományt a frissen létrehozott Lotaringia bombázócsoporthoz vezényelték, ahol annak egyik félszázadát alkotta Nancy elnevezéssel (a másik félszázad a Metz nevet kapta). ${ }^{37}$

A francia-német fegyverszünet megkötése után bizonytalanság uralkodott a francia gyarmati területeken állomásozó katonai erők körében, mivel az a szóbeszéd kelt lábra, mely szerint a fegyverszüneti feltételek rájuk nem vonatkoznak, ezért a gyarmati csapatok tovább folytatják a harcot. Ez a személyi állomány egy jelentős részének helyeslésével találkozott, így annál nagyobb volt a csalódás, amikor június végére egyértelmủen kiderült, hogy számukra a harc véget ért. Minden bizonnyal ez a csalódottság és a harc folytatása iránti elkötelezettség motiválta azokat a pilótákat (és esetenként müszaki állományban dolgozókat), akik úgy döntöttek, hogy gépeikkel vagy anélkül, de mindenképpen csatlakoznak az Észak-Afrikában és a Közel-Keleten állomásozó brit erőkhöz. Ennek eredményeként több tucat francia

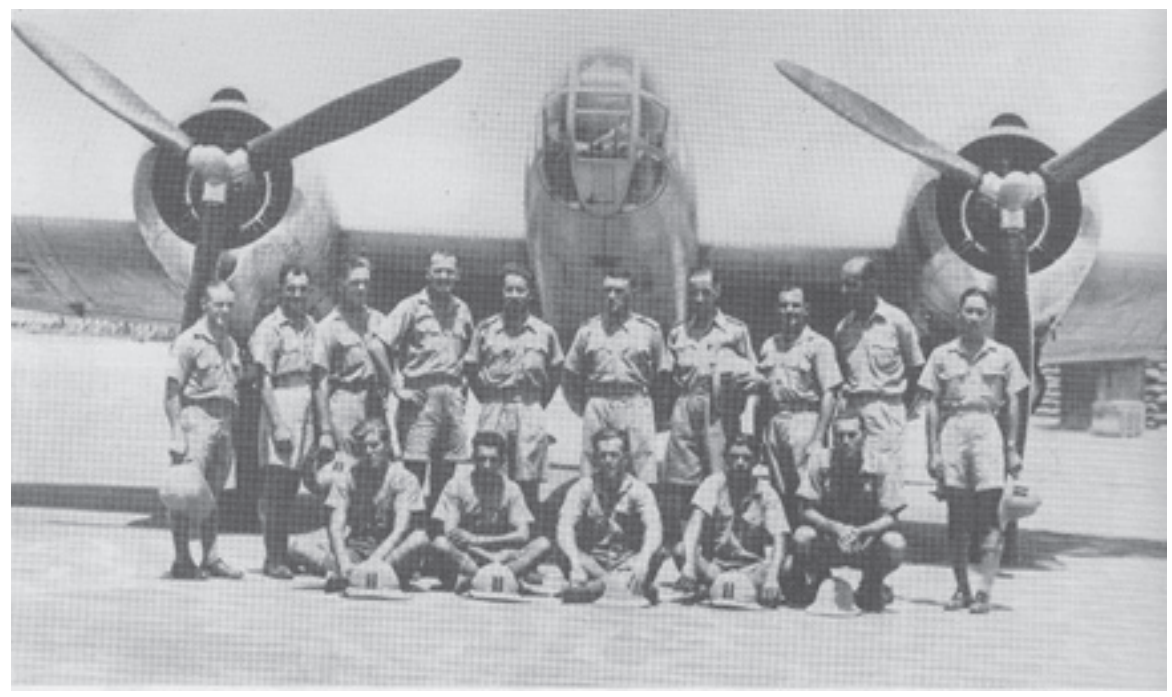

Glen Martin 167 bombázógép repülö- és müszaki személyzetével Kelet-Afrikában ${ }^{38}$ 
katona és közel egy tucatnyi repülőgép jelentkezett szolgálatra a helyi brit parancsnokságokon, amit azok - tekintettel a rendelkezésükre álló erők szűkösségére - örömmel fogadtak. Ezt az egyéni kezdeményezéseken alapuló együttműködést július 8-án tették hivatalossá, amikor a fenti erőkből három egységet állítottak fel: az 1., 2. és 3. szabad francia repülörajt (Free French Flight). ${ }^{39}$ Az 1. (bombázó)raj két Glenn Martin 167 bombázógéppel és 11 fös repülő és karbantartó személyzettel rendelkezett, ${ }^{40}$ a 2. (vadász)rajnak két Morane-Saulnier MS 406 vadászgépe ${ }^{41}$ és két Potez 63/11 felderítőgépe ${ }^{42}$ volt 17 fős állománnyal, ${ }^{43}$ míg a 3. (szállító- és összekötö) raj kötelékébe egy Caudron Simoun, ${ }^{44}$ egy Potez 25, egy Potez $29^{45}$ és egy Bloch 81 szállítógép ${ }^{46}$ tartozott ötfös személyzettel. ${ }^{47}$

A Ritoux-Lachaud százados vezetése alatt álló 1. rajt július 13-án Ádenbe irányították át, ahol a RAF 8. bombázószázadához csatlakozva az etiópiai hadszíntéren harcoló csapatokat kellett támogatniuk az olasz erők ellen. A mindössze két géppel rendelkező raj többtucat bombázó és felderítő bevetést teljesített 1940 második felében, amelyek során augusztus 16-án egy olasz bombázógépet is lelőttek, mely nagy valószínüséggel a Szabad Francia Légierő első légigyőzelme volt a háború folyamán. Az alakulat mindkét gépe odaveszett a harcok során, a 82-es számút szeptember 8-án, a 102-es jelzésüt pedig december 16-án lőtték le olasz vadászgépek.$^{48} \mathrm{~A}$ repülőgépek legénységéből két fő élte túl az akciókat, akik olasz hadifogságba kerültek, ahonnan 1941 áprilisában szabadultak ki. ${ }^{49}$

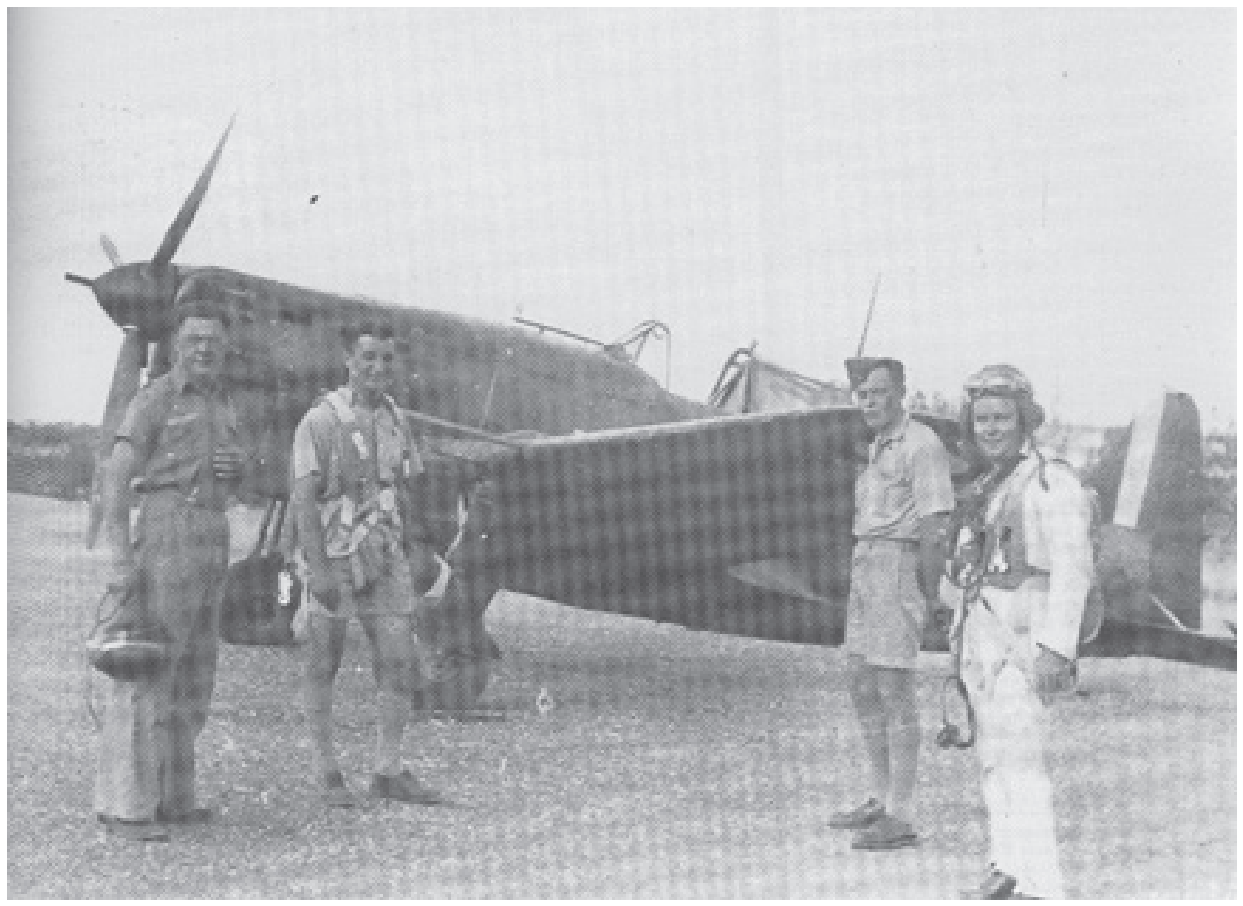

^ Készültségben lévö francia pilóták egy Morane 406 vadászgép elött Haifában 1940 októberében ${ }^{50}$ 
A 2. raj gépeit a brit parancsnokság Egyiptom, majd augusztus végétől Palesztina légterének védelmében használta fel. Mivel a német erők ekkor még nem voltak jelen, az olasz gépek berepülései pedig nem jelentettek különösebb fenyegetést, ezért a szolgálat során elsősorban a gépek karbantartása jelentett kihívást, nem pedig az ellenséges repülők támadásai. 1940 végére pótalkatrészek hiányában a raj gépei alkalmatlanná váltak a repülésre, ${ }^{51}$ ezért döntés született arról, hogy január folyamán Hurricane I repülőkkel szerelik fel, majd a megfelelő átképzés után márciustól a brit 74. repülőszázad kötelékében harcol tovább Egyiptom védelmében. ${ }^{52}$ Az egység tagjai 1941 tavaszán 15 légi győzelmet értek el, de májusban az egység parancsnokát, Jacquier századost lelőtték Kréta fölött és hadifogságba esett, ${ }^{53}$ majd három másik pilóta is veszteséglistára került. ${ }^{54}$ Mivel 1940. december 1-én a korábban a Topic alakulat soraiban Egyenlítői Afrikába irányított pilótákból felállították az 1. szabad francia vadászrepülő rajt James Denis hadnagy vezetésével, amely április 8-tól kezdve szintén Egyiptomban teljesített szolgálatot Hurricane gépeket ${ }^{55}$ repülve a 73. brit század kötelékében, ${ }^{56}$ ezért júniusban a két létszámalatti egység - mely már áprilistól kezdve együtt harcolt ${ }^{57}$ - hivatalosan is összeolvadt az utóbbi nevét megtartva ${ }^{58} \mathrm{Az}$ új alakulatot a korábbi rajok teljesítményének (165 harci bevetés során 17 légi győzzelem) ${ }^{59}$ elismeréseként június 1-én a Felszabadítási Érdemrenddel tüntették ki, így ez volt az első abból a 18 katonai alakulatból, amely a háború folyamán ebben a megkülönböztetett elismerésben részesültt. ${ }^{60}$

A 3. raj számos szállítási feladatot látott el 1940 második felében, melyek a müszaki személyzet áldozatos munkájának és a pilóták szakértelmének köszönhetően nem jártak gép- vagy emberveszteséggel. 1941 januárjában az egységet átnevezték French Communication Flight-nak, de ez nem érintette sem a gépparkot, sem a személyi állományt, amely ugyanolyan küldetéseket teljesített, mint korábban. ${ }^{61} 1940$ augusztusában feloszlatták, hogy az átszervezések keretében kialakított új légiszállítási rendszerbe nyerjen besorolást. ${ }^{62}$

A Szabad Francia Légierőnek a szárnypróbálgatás időszakában nagyon fontos segítséget jelentett a Csádban, Kamerunban és Gabonban állomásozó francia egyenlítői-afrikai légi alakulatok támogatása, amelyek összesen 26 darab szállító-, felderítö- és bombázógépet ${ }^{63}$ bocsátottak az új fegyvernem rendelkezésére ${ }^{64}$ Elsősorban ezek a gépek tették lehetővé, hogy a szabad francia területek közötti sürgős szállítási és kapcsolattartási feladatokat gyorsan és hatékonyan elvégezzék, így komoly szerep jutott nekik az új közigazgatás kiépítésében és fenntartásában, ${ }^{65}$ valamint a Kufra ellen indított támadó akció logisztikai támogatásában. Az Angliából útnak indított személyi és anyagi erősítések beérkezése után pedig erre alapozva vált lehetővé a Bretagne bombázócsoport felállítása 1941. december 31-én. ${ }^{66}$

\section{A repülőerők angol mintájú átszervezése és afrikai bevetése}

Az 1940 júliusának elején létrehozott légi haderő jelentős mennyiségi és minőségi fejlődésen ment át a következő egy év folyamán, de ennek ellenére a világ különböző pontjain szétszóródva tevékenykedő, kislétszámú, ${ }^{67}$ meglehetősen gyenge felszereltségű és változó szinten kiképzett erők, amelyek szigorú brit alárendeltségben 
tevékenykedtek, még messze voltak attól, hogy egy önálló és ütőképes fegyvernemet alkossanak. De Gaulle ezen a helyzeten kívánt változtatni, amihez egy „félállású” parancsnoknál, Muselier admirálisnál repülési ügyekben hozzáértőbb vezetőre volt szüksége a Szabad Francia Légierő élén, akit 1941 tavaszán Martial Valin repülös ezredes személyében talált meg. A francia légierő kötelékében tapasztalatokat szerző tiszt - akit elöször a Szabad Francia Légierő vezérkari főnökének, majd július 6-tól föparancsnokának neveztek $\mathrm{ki}^{68}$ - megfelelö tudással és tapasztalatokkal bírt ahhoz, hogy teljesítse De Gaulle kívánságát és a RAF szervezeti felépítését alapul véve önálló repülőegységeket (repülőszázadokat és -csoportokat) ${ }^{69}$ hozzon létre, amelyek katonailag és politikailag is nagyobb súlyt kölcsönözhettek a szabad francia mozgalomnak..$^{70}$

A cél megvalósításhoz feltétlenül szükséges volt a szövetséges hatalmak - és elsősorban Nagy-Britannia - beleegyezésének megszerzése, hiszen a már felállított kisebb-nagyobb repülő erők a hadmüveletek során ezek légierejének részeként kerültek bevetésre, valamint repülőgépekkel történő felszerelésük is szinte teljes egészében tőlük függött. Valin tárgyalási képességeit dicséri, hogy sikerült megszereznie a brit katonai vezetés támogatását ehhez a tervhez, valamint a szíriai hadjárat lezárása körüli feszült időszakban is elérte, hogy a levantei hadsereg tagjai közül önkénteseket toborozhasson a Szabad Francia Légierő számára. ${ }^{71}$ Ez különösen fontosnak bizonyult a jövő szempontjából, mivel egyrészt számos technikus választotta a szabad franciákat, akiknek a szakértelmére nagy szükség volt a harckészség fenntartásához, másrészt az itteni repülőterek használata és az azokon felhalmozott repülőanyag (gépek, fegyverek, tartalék alkatrészek) birtokba vétele hozzájárult a már meglévő egységek megerősítéséhez, illetve az új alakulatok kiképzéséhez. ${ }^{72}$

A megújult légierő felállításának, kiképzésének és bevetésének szerteágazó munkáját három, földrajzilag egymástól távol eső területen egyszerre kellett végrehajtani: Nagy-Britanniában, a Közel-Keleten és Szabad Francia Afrikában. A britekkel folytatott tárgyalásokon az az alapkoncepció született, mely szerint két bombázó- és két vadászrepülőcsoportot kell felállítani, melyeket a fenti hadszíntereken vetnek majd be a hadi helyzet alakulásának megfelelően. ${ }^{73}$ Időrendben az első ezek közül a Lotaringia (Lorraine) bombázócsoport volt, melynek szervezését augusztus folyamán kezdték meg Damaszkuszban elsősorban az 1. és 2. bombázócsoport személyi állományára, valamint másodsorban az Angliában és Szíriában jelentkezett új önkéntesekre építve Corniglion-Molinier örnagy parancsnoksága alatt. ${ }^{74} \mathrm{Az}$ ezt követő hat hét során a britektől kapott 20 Blenheim bombázón 24 legénységet sikerült kiképezni, ami lehetővé tette, hogy a csoportnak két 10 gépes százada legyen bevethető állapotban, amikor október folyamán áthelyezték egyiptomi állomáshelyére. Az egység a Nílus deltájának keleti részén, Fuka közelében elhelyezkedő tábori repterekről müködve november közepétől kezdve folyamatosan részt vett a németolasz páncéloserők ellen indított bombázóakciókban. ${ }^{75}$ A nehéz időjárási viszonyok ellenére az alakulat a következő két hónap során 388 bevetést teljesített ${ }^{76}$ melyek során 173 tonna bombát dobott le és jelentős károkat okozott az ellenségnek, mellyel kiérdemelte a 270. brit bombázócsoport parancsnokának dicséretét is. Ugyanakkor a 
veszteségek is jelentősek voltak: a csoport 8 gépet és 6 legénységet veszített a harcok során, köztük az egység december 17-én kinevezett új parancsnokát, Charles Pijeaud ezredest, ${ }^{77}$ akit első bevetésén lőttek le. Ez is hozzájárult ahhoz, hogy 1942. január 20-án a Lotaringiát Libanonba küldték pihenőre, hogy pótolja veszteségeit, amelyet többek között a navigátorok pilótává történő átképzésével valósítottak meg. ${ }^{78}$

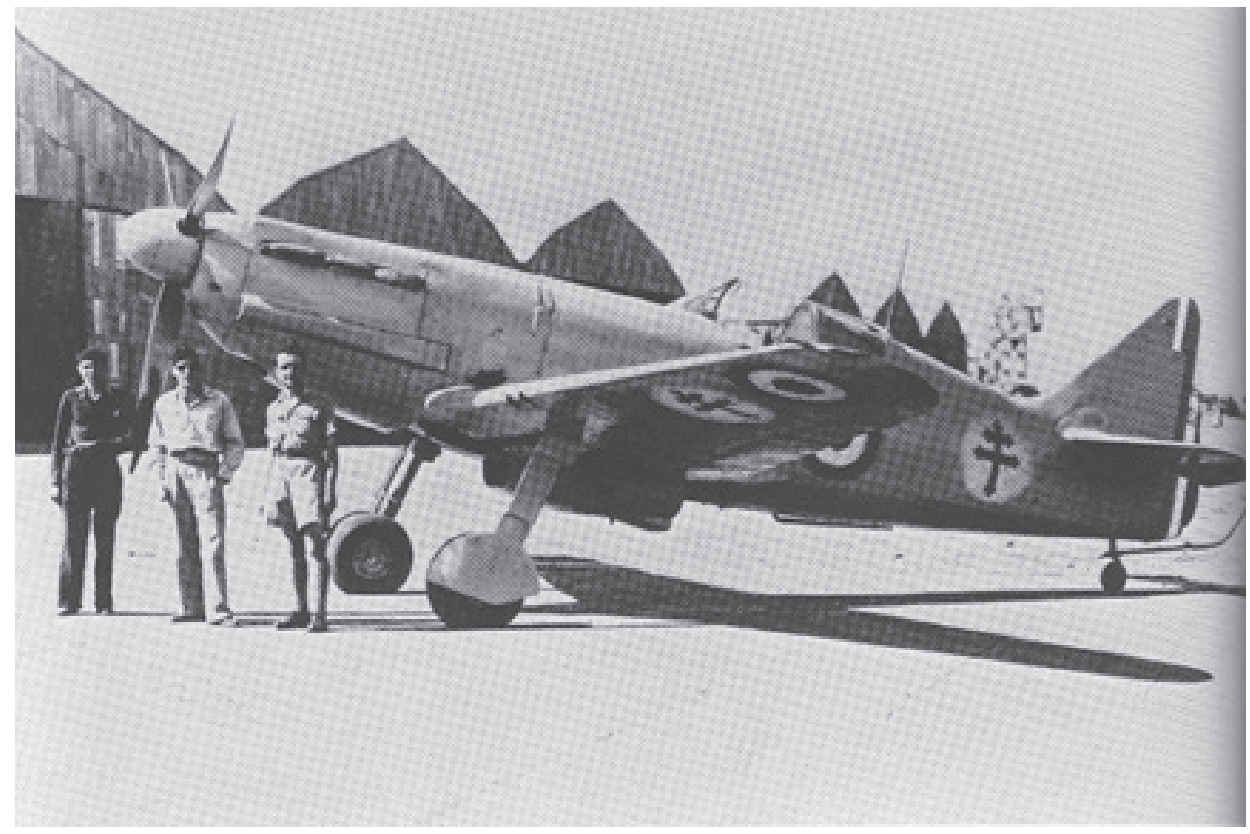

\Szabad francia vadászgép Libanonban 1942-ben ${ }^{79}$

A brit parancsnokság a feltöltési célzatú pihenő alatt is talált feladatot a francia pilóták számára. A csoport két századát (melyek létszámukat tekintve ekkor inkább repülőrajnak feleltek meg) eltérő helyeken és célokkal használták fel 1942 tavaszán és nyarán. A Metz század állományát saját gépeiket hátrahagyva az utánpótlásként érkező gépek szállítására használtak fel, melynek során ázsiai és afrikai kikötőkből repülték át a tengeri úton érkezett gépeket az észak-afrikai hadszíntérre. Ez idő alatt a Nancy század csatlakozott a RAF közel-keleti partvédelmi századához és Akkó központtal felderítő és tengeralattjáró-elhárító repüléseket végzett a Földközi-tenger keleti medencéjében. ${ }^{80} \mathrm{~A}$ tengeri repülések során két tengeralattjárót fedeztek fel és támadtak meg, melyek közül az egyik megrongálását ismerte el számukra a felettes parancsnokság. ${ }^{81}$ Szeptemberben döntés született az alakulat áthelyezéséről Nagy-Britanniába, ahová a szabad francia katonák több hullámban 1943 első hónapjaiban érkeztek meg hosszú és viszontagságos tengeri út után, melynek során az egység állományának egy része odaveszett egy tengeralattjáró-támadás során. ${ }^{82}$ A brit Légügyi Minisztérium döntése értelmében az alakulat a 342. szabad francia 
századként kétmotoros Boston könnyübombázókkal ${ }^{83}$ felszerelve folytatta pályafutását. A szükséges típusátképzés után a Lotaringia 1943 júniusától teljesített harci szolgálatot a 137. brit repülőcsoport soraiban, melynek keretében a megszállt Európa felett repült. ${ }^{84}$ Bár az eredeti célok szerint a Lotaringiának két századból álló önálló repülöcsoportként kellett tevékenykednie, 1943-ra az elszenvedett veszteségek miatt a bevethető személyi állomány már csupán egy század felállítását tette lehetővé, így minden bizonnyal ez magyarázza a brit egységbe történő besorolást is, mely egyben az eredeti elképzelés részleges kudarcát is jelentette.

De Gaulle 1941. augusztus 27-i döntése értelmében két szabad francia vadászrepülő csoportot kellett felállítani a rendelkezésre álló erőkre építve, egyet a Közel-Keleten, egyet pedig Angliában. Az előbbi az Elzász (Alsace) nevet kapta és kezdetben a korábban a térségben harcoló 1 . és 2. vadászrepülőraj pilótáit fogta össze. ${ }^{85}$ Ehhez a személyzethez nagy számban csatlakoztak repülős kiképzésüket Nagy-Britanniában befejező francia pilóták és müszakiak ${ }^{86}$ (a korábban itt állomásozó Vichy-lojalitású vadászalakulatból ugyanakkor csupán két müszaki katona választotta a szabad francia alakulatot) ${ }^{87}$ akik Jean-Louis Tulasne százados vezetése alatt együtt alkották az új egység személyi állományát. A repülőcsoportnak 14 darab MS 406, 4 darab Potez 25 és egy darab Potez 29, egy darab Curtiss P-36, ${ }^{88}$ valamint egy darab Simoun gépe volt, melyek nagy részét a Levantei Hadsereg légiereje által hátrahagyott felszerelésből zsákmányolták és állították szolgálatba. Az egységhez 20 pilóta, 30 müszaki és 82 egyéb beosztású katona tartozott, akik a Strasbourg és Mulhouse századok kötelékében teljesítettek szolgálatot. ${ }^{89}$ A következő hónapokat az Elzász kiképzéssel töltötte, amely jót tett a pilóták felkészültségének, ugyanakkor egyértelművé vált, hogy az elhasznált és tartalék alkatrészekkel nem rendelkező francia gépek nem alkalmasak a harctéri körülmények közötti müködésre, amit több halálos repülőbaleset is bizonyított. Ennek megfelelően kérték a brit hadvezetést, hogy Hurricane vadászgépekkel lássa el az egységet, amelyet az meg is ígért, de a rendelkezésre álló gépállomány szűkössége miatt a gépek szállítása csak 1942 januárjában történt meg, ${ }^{90}$ azonban a francia alakulat ekkor is csak a Hurricane régebbi I-es típusát kapta meg, mely már elavult, ráadásul a gépek erősen elhasználtak voltak, ezért a pilóták öröme nem volt felhőtlen. ${ }^{91}$ A típusátképzéshez az alakulatot áthelyezték Egyiptomba, Alexandria térségébe, ahol a személyzet három hónapot töltött, mielőtt április elején bevetésre alkalmasnak minősítették. ${ }^{92}$ 


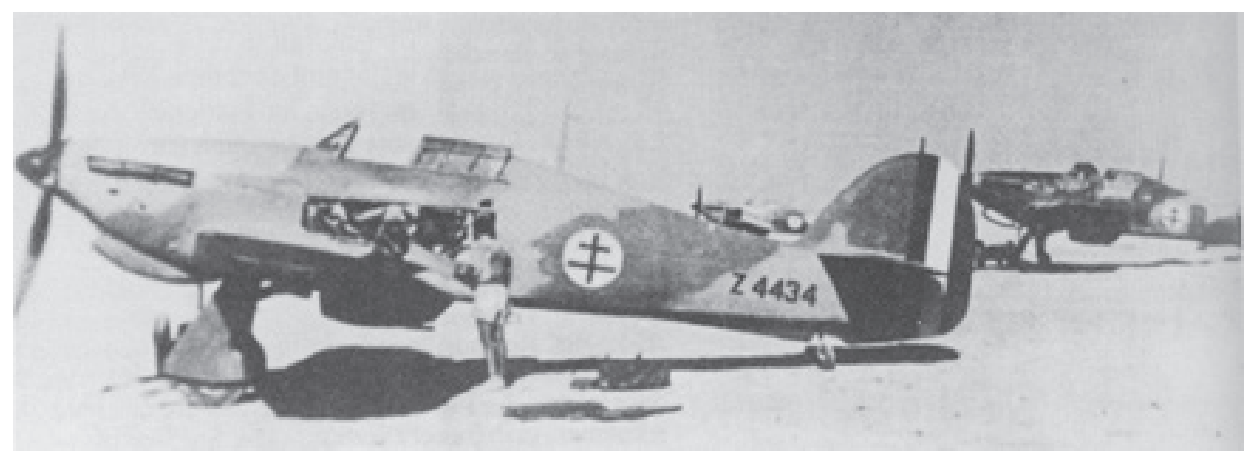

Az Elzász repülőcsoport Hurricane vadászgépei Egyiptomban ${ }^{93}$

Az egység a harci bevetéseket Fukából kezdte meg és június elejéig elsősorban tengeri konvojok védőkíséretét, valamint a brit kézen lévő területek feletti járőrözést látta el, amelyek során a francia pilóták ritkán találkoztak ellenséges gépekkel, így érdemi légi harcokra sem került sor. ${ }^{94}$ Május végén Tulasne-t az Elzász öt pilótájával együtt áthelyezték a leendő Normandia repülőcsoportba (amelynek történetére itt nem térünk ki részletesebben), ${ }^{95}$ így helyét az egység élén korábbi helyettese, Pouliquen örnagy vette át. A vadászrepülők első veszteségeiket június 13-án szenvedték el, amikor egy éjszakai távolsági bevetés után több gépnek is kifogyott az üzemanyaga, ezért kényszerleszállást hajtottak végre, amelynek során két pilóta meghalt. ${ }^{96} 27$-én öt gép veszett oda a német 27 vadászrepülö-ezred ${ }^{97}$ ellen vívott légi harcokban ( 2 halott, 3 sérült pilóta),$^{98}$ aminek eredményeként csak nyolc bevethető pilóta maradt az alakulatban, amelynek közben folyamatosan kelet felé kellett visszahúzódnia Rommel sikeres offenzívája miatt. Július és augusztus folyamán a létszámalatti csoport (gyakorlatilag inkább század) Alexandria légvédelmében vett részt, miközben megkezdődött felszerelése Hurricane II gépekkel. Ezzel egyidőben értesítették az alakulat tagjait, hogy áthelyezik őket Nagy-Britanniába, így afrikai szolgálatuk, mely során 750 bevetésen a korábban említett veszteségek árán egy ellenséges gépet semmisítettek meg és öt másiknak okoztak sérülést, véget ért. ${ }^{99}$ A személyi állományt október 24-én hajózták be Szuezben, hogy egy tízhetes út után január 1-én érkezzenek meg Skóciába, ${ }^{100}$ ahol 1943. január 21-én René Mouchotte őrnagy parancsnoksága alatt a RAF 341. repülőcsoportjaként Spitfire Vb gépekkel felszerelve kezdték meg újbóli kiképzésüket Turnhouse-ban. ${ }^{101}$ A típusátképzés február 2. és 17. között gyors ütemben zajlott le, majd ezt követően a századot Biggin Hill-be helyezték át, ${ }^{102}$ ahol április 3-tól harci bevetéseket teljesített, de ekkor már folyamatosan érkeztek számára a modernebb Spitfire IX vadászgépek. Az április elejétől augusztus végéig terjedő időszakban az Elzász pilótái 1.600 harci bevetésen vettek részt, melyek során 26 megerősített és 4 lehetséges légi győzelmet arattak, valamint 11 ellenséges gépet megrongáltak, miközben hat pilótát veszítettek. ${ }^{103}$

A másik szabad francia vadászrepülő csoport Île-de-France néven Angliában került felállításra. Ez az új alakulat gyakorlatilag teljesen megegyezett a RAF 
korábban már említett 340. csoportjával, amelyet 1941. november 7-én a skóciai Turnhouse-ban hoztak létre. ${ }^{104}$ Afrikai érintettség hiányában ennek történetére sem térünk ki bőveben.

A Csádban állomásozó meglehetősen vegyes gépparkkal rendelkező (szállító-, felderítő- és bombázógépek) és alacsony harcértékű repülőerőkből 1942. január 1-én állították fel a Bretagne bombázócsoportot azzal a céllal, hogy hatékonyabban tudja támogatni Leclerc ezredes líbiai támadó hadmüveletét. ${ }^{105} \mathrm{~A}$ repülőcsoport első százada, mely a Rennes nevet viselte, hat Lysander géppe ${ }^{106}$ Moussoro városába települt, a második, Nantes elnevezésủ század Fort Archambault-ban állomásozott három Glenn Martin-nal, ${ }^{107}$ míg a futárgépek Fort Lamy-ban maradtak. ${ }^{108}$ Leclerc a teljes bevethető gépállományt felhasználta első fezzani hadjárata során 1942 februárjában és márciusában, amikor rajtaütés-sorozatot hajtott végre a dél-líbiai olasz helyőrségek ellen. A Bretagne gépei a hadművelet során számos felderítő és bombázó bevetést teljesítettek, melyek elősegítették a szárazföldi csapatok (korlátozott) sikerét. ${ }^{109}$ Ugyanakkor az akció során az is egyértelmüen kiderült, hogy a rendelkezésre álló gépek - melyek számos alkalommal hajtottak végre kényszerleszállást a hadmüvelet alatt - elavultak és rossz müszaki állapotban vannak, így annak ellenére, hogy a Bretagne a többi csádi egységgel együtt kitüntetésben részesült, hosszútávon komoly müszaki problémákkal kellett szembenéznie, amelyet legegyszerübben új repülők csatasorba állításával lehetett volna orvosolni. ${ }^{110}$

A szűkös utánpótlási lehetőségek ennek ellenére nem tették lehetővé a géppark megújítását, csupán néhány használt gép szállításával tudták javítani az alakulat harcértékét 1942 nyarán. Ennek eredményeként év végén a Rennes század négy Lysander, a Nantes század pedig három Glenn Martin és négy Blenheim típusú géppel rendelkezett, valamint számos kisebb összekötö- és szállítógép egészítette ki az állományt, amely összesen 18 repülőből állt.. ${ }^{111} \mathrm{~A}$ Leclerc által megindított december második felében megindított második fezzani hadjárat során a repülőcsoport harci gépei 41 bevetést teljesítettek, melyek során három gépet veszítettek. Teljesítményüket jól illusztrálja az a különleges eset, amikor január 9-én az egyik bombázó egy 140 fös olasz hadoszlopot kényszerített megadásra minden külső segítség nélkül. Az összekötő gépek által biztosított utánpótlás legalább ilyen fontosnak bizonyult, így a Bretagne a rendelkezésére álló eszközökhöz mérten eredményesen vett részt az ez alkalommal teljes sikerrel záruló dél-líbiai hadjáratban. ${ }^{112}$

A hatékony közremüködésnek azonban ára is volt, mivel a repülöcsoport egyébként is öreg gépei annyira elhasználódtak a hadmüvelet során, hogy további harci felhasználásra teljesen alkalmatlanná váltak. ${ }^{113}$ Ezen felül az egység pilótái nem rendelkeztek tapasztalattal az angolszász szövetségesekkel való együttmüködésben, nem ismerték elég jól sem a brit repülési szokásokat, sem a nyelvet, így a problémák elkerülése érdekében a hadjárat további részében, mely már a britekkel közösen zajlott Tunéziában, nem számoltak a Bretagne részvételével. Az egység új feladatra és új gépekre várva kiképzéssel töltötte 1943 tavaszát és nyarát, ${ }^{114}$ miközben a szabad francia hadvezetés, mely hiába várt a nyugati szövetségesektől támogatást az alakulat újrafelfegyverzéséhez, tárgyalásokat folytatott annak esetleges bevetéséről 
a keleti hadszíntéren. A szovjet fél kedvezően fogadta a javaslatot, ezért a Bretagne-t augusztus végén áthelyezték Szíriába, hogy onnan folytassa útját a Szovjetunióba. Az utolsó pillanatban az amerikai hadvezetés közbeszólt és jelezte, hogy korábbi állásfoglalásával ellentétben hajlandó gépekkel ellátni az egységet, ezért végül a Bretagne Francia Észak-Afrikába települt vissza, ahol a 31. repülőezred részeként B-26 Marauder közepes bombázókkal ${ }^{115}$ szerelték fel. Ezzel a lépéssel az alakulat önállósága megszünt, a háború végéig ennek a magasabb egységnek a kötelékében teljesített szolgálatot és vett részt a megszállt európai országok felszabadításában. ${ }^{116}$

Az újjászervezett Szabad Francia Légierő kötelékén belül volt két olyan egység, mely földrajzi elhelyezkedésüknél és feladatuk jellegénél fogva kevésbé ismertek a többi alakulatnál, ezek pedig a tengeri járőrözést folytató Artois és Pikárdia (Picardie) repülöcsoportok.

Bár a közép-afrikai francia területeken rendelkezésre álló szegényes gépállományt felhasználva már 1942 júliusától müködött egy partvédelmi repülőcsoport Kamerunban és Gabonban, az Artois hivatalosan csupán 1943. január 27-én jött létre Kopp örnagy vezetése alatt. Az egységet alkotó Arras és Béthune századok összesen 10 könnyű repülőgéppel és 51 fős személyi állománnyal igyekeztek más szövetséges repülőalakulatokkal gondoskodni a térségen áthaladó tengeri konvojok biztonságáról és ezzel párhuzamosan az ellenséges tengeralattjárók megsemmisítéséről. A kevéssé látványos feladat nagyon fontos volt a hadszíntereken harcoló csapatok ellátásának biztosításához, ezért a brit hadvezetés 1943 folyamán Avro Anson ${ }^{117}$ és Vickers Wellington kétmotoros gépekkel ${ }^{118}$ szerelte fel az alakulatot, ${ }^{119}$ mely a világháború befejezéséig látta el ezt a szolgálatot a régióban. ${ }^{120}$

Damaszkuszban 1942 végén állítottak fel egy hasonló feladatokkal megbízott 10 gépből álló repülőegységet, amely hivatalosan 1943 júniusában vette fel a Pikárdia nevet. Repülőgép-állományát a Levantei Hadsereg által hátrahagyott, valamint a többi szabad francia alakulat által átadott különböző típusú francia és brit gyártmányú gépek alkották. Az egység, melynek gépei Damaszkusz mellett Palmürában 
és Hassetchében állomásoztak, a földrajzi sajátosságok miatt nem csupán a tenger, hanem a sivatag fölött is teljesített felderítő repüléseket. Az angolszász szövetségesek segítségével a csoport első százada Douglas A-24, ${ }^{121}$ a második pedig A-30 Baltimore $\mathrm{V}$ bombázókat ${ }^{122}$ kapott, melyek jelentősen növelték harcértékét. Ennek köszönhetően az első századot át is helyezték Észak-Afrikába, ahonnan a Vendée repülőcsoport részeként vett részt Franciaország felszabadításában. ${ }^{123}$

A harcoló alakulatok mellett a szabad francia mozgalom számára nagy jelentőséggel bírt az ún. katonai légi útvonalak (lignes aériennes militaires) kiépítése, amelyek azokat a légi szállítókapacitásokat fogták össze, melyeknek köszönhetően a Szabad Franciaország külső segítség nélkül volt képes a francia és szövetséges területek között kapcsolatokat fenntartani, illetve kiemelt fontosságú személyeket és küldöttségeket, valamint korlátozott mennyiségben utánpótlást szállítani. Az első légi útvonal felállítására 1941. szeptember 8-án került sor Damaszkusz és Kairó között, melyet gyors ütemben számos másik követett, amelyek Nyugat-Afrikától egészen Moszkváig hálózták be a francia érdekeltségü területeket. A Damaszkusz központtal működő rendszer élére, mely katonai és civil pilótákat is összefogott, Lionel de Marmier ezredest nevezték ki, aki központi szerepet játszott a szervezet kiépítésében és hatékony müködtetésében, valamint számos alkalommal személyesen vezette a De Gaulle tábornokot szállító repülögépet afrikai és közel-keleti útjai során. $^{124}$

\section{Összefoglalás}

A Szabad Francia Légierő soraiban szolgálok száma a vizsgált időszakban folyamatosan növekedett, ahogy a szárazföldi csapatok kötelékéből és az emigráns civilek közül egyre többen jelentkeztek az új fegyvernem soraiba, így végül 1940 és 1943 között összesen körülbelül 5.000 fő teljesített repülős szolgálatot, ugyanakkor azonban az egyidőben bevethető szabad francia harci személyzet létszáma soha nem haladta meg az 1.200 föt. ${ }^{125} \mathrm{~A}$ fegyvernem katonai jelentőségét jól érzékelteti, hogy ugyanezen időszakban 546 csehszlovák és 1.813 lengyel önkéntes teljesített harci szolgálatot a brit légierő kötelékén belül, tehát a francia részvétel nem tekinthető sem kivételesnek, sem pedig különösebben számottevőnek. ${ }^{126} \mathrm{~A}$ fenti tényt tovább árnyalja, hogy míg az első önálló csehszlovák és lengyel repülőszázadok 1940. július elején alakultak meg Nagy-Britanniában, a szabad franciák esetében ugyanerre november elejéig kellett várni a jelentkezők alacsony létszáma miatt. ${ }^{127}$

Objektíven szemlélve a szabad francia repülőerők helyzetét, noha hatalmas erőfeszítések árán hozták létre őket és számos ember áldozatos munkájának következtében tudtak müködni, korlátozott létszámukból kifolyóan katonai szempontból nem nyújtottak olyan teljesítményt, amely különösebb elismerést váltott volna ki a háború során.

Ugyanakkor önmagában az a tény, hogy az 1940-ben elszenvedett francia vereséget követően a tengelyhatalmakkal szemben Afrikában is egyedül maradt Nagy-Britannia oldalán egy harcba vethető - még ha szerény - erőket is magába foglaló légierő sorakozott fel, kritikus időszakban jelentett értékelhető katonai 
segítséget a szigetország számára. Ebből kifolyólag ez a szerepvállalás komoly politikai jelentőséggel bírt és kivívta a brit politikai vezetés háláját, amely a háború során - a kisebb-nagyobb konfliktusok ellenére is - kiállt a De Gaulle vezetése alatt álló Harcoló Franciaország mellett, ami komoly segítséget jelentett a szabad francia mozgalom nemzetközi helyzetének megszilárdításához.

\section{Jegyzetek}

1 Facon 2005, 255-262.

2 AN 72 AJ 239. Les Forces Aériennes Françaises Libres 1940-1942, 3.

3 Az már egy másik kérdés, hogy annyira mostoha körülmények között helyezték el öket, hogy tizenöten kérelmezték hazaszállításukat Franciaországba. AN 72 AJ 239. Chasse libre (1), 3.

4 AN 72 AJ 239. Chasse libre (1), 7.

5 Perrot 1990, 115.

6 Dupérier 1990, 52.

7 Ezek az 1., 64., 92., 111., 213., 245., 249. és 615. repülöszázadok voltak. AN 72 AJ 239. Annexes de l'exposé du G. C. Haslam, 7-8.

8 AN 72 AJ 239. Chasse libre (1), 4.

9 Lafont 1990a, 29-47.

10 AN 72 AJ 239. Les Forces Aériennes Françaises Libres 1940-1942, 7.

11 AN 72 AJ 239. Chasse libre (2), 3.

12 Az 1930-as évek közepén tervezett egyfedelü vadászrepülőgépet 1938-ban állították szolgálatba. Jó manőverezőképességének, jelentős tüzerejének és egyszerü vezethetőségének köszönhetöen a háború egyik legsikeresebb repülögépe lett, melynek különböző továbbfejlesztett altípusaiból több mint 20.000 példányt gyártottak. Munson 1995, 211-214.

13 AN 72 AJ 239. Annexes de l'exposé du G. C. Haslam, 9., 15.

14 AN 72 AJ 239. Chasse libre (2), 15.

15 AN 72 AJ 239. Les Forces Aériennes Françaises Libres 1940-1942, 8.

16 AN 72 AJ 239. Bombardement à la carte (1), 8.

17 AN 72 AJ 239. Chasse libre (1), 8.

18 AN 72 AJ 239. Bombardement à la carte (1), 8-9.

19 Charles 1964, 101.

20 Chaline-Santarelli 1989, 398.

21 Millet 1987, 19.

22 AN 72 AJ 239. Bombardement à la carte (1), 11 .

23 Buffotot 1980, 186.

24 Charles 1964, 112.

25 Vincent 1983, 7.

26 AN 72 AJ 239. Note sur le groupe Lorraine et sur le lieutenant-colonel Lionel de Marmier, 1.

27 AN 72 AJ 239. Les Forces Aériennes Françaises Libres 1940-1942, 11.

28 AN 72 AJ 239. Bombardement à la carte (2), 2.

29 Broche 2002, 189-190.

30 Donjon 2002, 55.

31 AN 72 AJ 239. Note sur le groupe Lorraine et sur le lieutenant-colonel Lionel de Marmier, 2.

32 AN 72 AJ 239. Annexes de l'exposé du G. C. Haslam, 51.

33 A Martin XA-22 vagy Martin 167, illetve Maryland néven is ismert repülögép egy amerikai gyártású könnyűbombázó és felderítőgép volt, amelyet a brit és a francia légierő részére gyártottak, ahol 1940-ben álltak szolgálatba. Összesen 450 darabot állítottak elö a típusból, amelynek egyes példányait jó manőverezőképességüknek és 800 kilogrammos bombaszállítási képességüknek köszönhetően 1945-ig használták. Munson 1995, 396. 
34 AN 72 AJ 239. Les Forces Aériennes Françaises Libres 1940-1942, 12.

35 Bauden 1989, 121.

36 AN 72 AJ 239. Bombardement à la carte (2), 7-8.

37 AN 72 AJ 239. Note sur le groupe Lorraine et sur le lieutenant-colonel Lionel de Marmier, 2.

38 Cunibil 1989, 86.

39 Jacquier 1989, 35-36.

40 AN 72 AJ 239. Bombardement à la carte (1), 6.

41 Az 1938-ban szolgálatba állított francia gyártmányú egyfedelü vadászrepülőgép a francia légierő legnagyobb számban használt elfogó vadásza volt a háború kitörésekor, amelyböl összesen 1.037 darabot gyártottak. A modern gépet sikerrel vetették be a német repülők ellen az 1940-es francia hadjárat során, valamint számos másik országba exportálták. Munson 1995, 360-361.

42 A Potez 63 kétmotoros többfeladatú gépet 1938-ban állították szolgálatba, mint vadász, csatarepülő, könnyü- és zuhanóbombázó, illetve felderítő repülőgépet. 63/11-es háromfös személyzettel repülő altípusát kifejezetten felderítő feladatok ellátására tervezték és 717 példányt gyártottak belőle részben a hazai légierő, részben külföldi megrendelők részére. Munson 1995, 362-363.

43 AN 72 AJ 239. Chasse libre (1), 15.; Lafont 1989, 12.

44 Az 1935-ben szolgálatba álló francia gyártású egymotoros könnyủ polgári repülőgépet a francia légierő összekötő és felderítő repülőként használta 1936-tól a háború végéig. 500 darab készült belöle 1940-ig. Munson 1995, 346.

45 Az 1920-as éve közepén szolgálatba állított Potez 25 egymotoros kétfedelü könnyű repülő alkalmas volt könnyübombázó, felderítő és összekötő feladatok ellátására is. Ennek megfelelően 4.000 példányt gyártottak belőle, amelyeket aktívan használtak a két világháború közti időszakban, illetve a második világháború elején. 29-es altípusát kifejezetten szállítási feladatok kivitelezésére tervezték. Facon 2005, 273.

46 A Bloch 81-es egymotoros könnyü sebesültszállító repülőt 1934-ben állították szolgálatban és 1942-ig használták. Az egy sebesült szállítására alkalmas gépből mindössze 21 példány készült. Facon 2005, 275.

47 Geiger 1989, 99-100.

48 AN 72 AJ 239. Bombardement à la carte (1), 7.

49 Cunibil 1989, 84-88.

50 Lafont 1989, 13.

51 Delpech 1989, 115.

52 AN 72 AJ 239. Chasse libre (1), 16.

53 Jacquier 1989, 37-41.

54 Geiger 1989, 106.

55 Az 1937 végén szolgálatba állított angol gyártmányú Hawker Hurricane a brit Királyi Légierő első alsószárnyas vadászgépe volt, amely elfogóvadászként és vadászbombázóként nagyon sikeres karriert futott be a második világháború során. Különböző altípusaiból 14.533 darabot gyártottak, amelyet az összes hadszíntéren bevetettek. Munson 1995,115-118.

56 AN 72 AJ 239. Chasse libre (1), 10.

57 Ballatore 1989, 77.

58 Ennek elsődleges oka az volt, hogy a 2. raj összes pilótája meghalt, eltűnt vagy megsebesült a bevetések során, így a folytonosságot az 1. raj képviselte. AN 72 AJ 239. Chasse libre (1), 18.

59 Trouplin 2010, 1113.

60 Denis 1989, 44-52.

61 AN 72 AJ 239. Annexes de l'exposé du G. C. Haslam, 55.

62 Geiger 1989, 109.

63 AN 72 AJ 239. Annexes de l'exposé du G. C. Haslam, 29. 
64 Saint-Péreuse 2002, 95.

65 AN 72 AJ 239. Bombardement à la carte (1), 4.

66 AN 72 AJ 239. Bombardement à la carte (2), 9.

67 A szabad francia repülőszemélyszet létszáma 1941 elején nem haladta meg az 500, 1942 első hónapjaiban pedig az 1.200 föt. Perrot 1990, 115.

68 AN 72 AJ 220. Témoignage du général Martial Valin, 1-6.

69 A brit légierőben egy repülőszázad 12 gépből állt. Két ilyen század alkotott egy repülőcsoportot, amely taktikailag önállóan müködött, 3 vagy 4 csoport pedig egy repülőezredet tett ki. Clostermann 1948, 333.

70 Broche 2002, 192-193.

71 AN 72 AJ 220. Témoignage du général Martial Valin, 9-10.

72 AN 72 AJ 239. Annexes de l'exposé du G. C. Haslam, 47-48.

73 AN 72 AJ 239. Les Forces Aériennes Françaises Libres 1940-1942, 12.

74 AN 72 AJ 239. Bombardement à la carte (3), 4.

75 AN 72 AJ 239. Annexes de l'exposé du G. C. Haslam, 37.

76 AN 72 AJ 239. Note sur le groupe Lorraine et sur le lieutenant-colonel Lionel de Marmier, 3.

77 SHD AC 21 P. 134577.

78 AN 72 AJ 239. Bombardement à la carte (3), 16-17.

79 Pange 1972, 158.

80 AN 72 AJ 239. Annexes de l'exposé du G. C. Haslam, 37.

81 AN 72 AJ 239. Bombardement à la carte (3), 17.

82 AN 72 AJ 239. Annexes de l'exposé du G. C. Haslam, 37-39.

83 A Douglas A-20 Boston (Havoc) amerikai gyártmányú bombázógép volt, amelyet 1940-ben állítottak szolgálatba az Egyesült Államokban, de jelentős számban exportálták a szövetséges államok légieröi részére is. Sikeresen teljesített könnyűbombázóként és éjszakai vadászként is, a háború végéig 7.385 darab készült belöle. Munson 1995, 79-92.

84 AN 72 AJ 239. Note sur le groupe Lorraine et sur le lieutenant-colonel Lionel de Marmier, 4.

85 Charrasse 1990, 75.

86 Lafont 1989, 20.

87 Delpech 1989, 119.

88 Az amerikai gyártmányú Curtiss P-36 (H. 75) az egyik első teljes fémépítésű modern alsószárnyas vadászrepülőgép volt az Egyesült Államok légierejében, amely 1938-ban állt szolgálatba, de a háború kitörésekor már elavultnak számított. A 845 legyártott példány közel fele a francia légierő kötelékében repült, ahol gyenge fegyverzete és alacsony sebessége ellenére fordulóharcban való kiválóságának és ellenálló szerkezetének köszönhetően nagyra becsülték és 1940 során számos légi győzelmet arattak vele. Munson 1995, 257.

89 AN 72 AJ 239. Chasse libre (2), 9.

90 Pouliquen 1990, 17.

91 Boisot 1990, 73.

92 Denis 1989, 53.

93 Lormier 2006, képmelléklet, 4. kép.

94 Lafont 1990b, 27-29.

95 A pilóták maguk kérték áthelyezésüket, mivel túlságosan eseménytelennek találták az északafrikai szolgálatukat, bár távozásukkal aláásták az egységben maradó társaik harci kedvét.

Raoul-Duval 1990, 42.

96 Ezanno 1990, 34-36.

97 Jagdgeschwader 27 (JG 27).

98 Giocanti 1990, 82.

99 AN 72 AJ 239. Chasse libre (2), 10-11.

100Lorrain 1990, 155-157. 
101 AN 72 AJ 239. Les Forces Aériennes Françaises Libres 1940-1942, 15.

102 Jaeger 1990, 106.

103 AN 72 AJ 239. Chasse libre (2), 12-14.

104 AN 72 AJ 239. Les Forces Aériennes Françaises Libres 1940-1942, 8.

105 AN 72 AJ 239. Bombardement à la carte (4), 2.

106A brit gyártmányú Westland Lysander futárgépet 1938-ban állították szolgálatba és 1944ig tartó alkalmazása során kiemelkedően sikeres volt a megszállt területeken tevékenykedő ellenálló mozgalmakkal való kapcsolattartás lebonyolításában. 1.593 darabot gyártottak belöle. Munson 1995, 221-222.

107 Létszámuk és harcértékük alapján ezek az egységek a valóságban inkább rajnak tekinthetők, semmint századnak.

108 Broche 2002, 195.

109Millet 1987, 21.

$110 \mathrm{AN} 72 \mathrm{AJ} 239$. Bombardement à la carte (4), 3-7.

111 Vincent 1983, 291.

112 AN 72 AJ 239. Bombardement à la carte (4), 12-14.

113 Millet 1987, 22-23.

114 Saint-Péreuse 2002, 99.

115 A Martin B-26 Marauder kétmotoros amerikai közepes bombázó 1942-ben állt szolgálatba. A hétfős személyzettel ellátott kéttonnás teherbíró képességgel rendelkező jól védett gép a kezdeti müszaki problémák után kiemelkedően sikeres pályafutást tudhatott magáénak. Összesen 5.157 darab készült belöle. Munson 1995, 162-163.

116 AN 72 AJ 239. Bombardement à la carte (4), 15.

117 Az 1936-nan szolgálatba állított angol gyártmányú kétmotoros Avro Anson felderítö- és iskolagép a háború egész ideje alatt (és azt követően is) megbízhatóan szolgált, legfontosabb feladatköre a partvédelmi felderítés volt. 8.183 példányt gyártottak belőle. Munson 1995, 44-45.

118 A Vickers Wellington az egyik legsikeresebb angol gyártmányú közepes bombázó- és felderítőgép volt, amely ellenálló szerkezetének és nagy teherbíró képességének köszönhetően alacsony saját veszteségek mellett jelentős károkat okozott az ellenségnek bevetései során. A 11.461 legyártott példány jelentős része partvédelmi szerepkörre volt optimalizálva. Munson 1995, 217-220.

119 Marchand 2002. 31.

$120 \mathrm{AN} 72$ AJ 239. Bombardement à la carte (5), 2-10.

121 Az amerikai gyártmányú Douglas A-24 (SBD) Dauntless könnyűbombázó és felderítő 1940ben állt szolgálatba és viszonylag elavultnak számított, ennek ellenére rendkívül sikeresnek bizonyult a csendes-óceáni harcok során. Harctéri eredményeinek többségét zuhanóbombázó feladatkörben érte el. Összesen 5.936 darabot gyártottak belőle. Munson 1995, 87-88.

122 A Martin A-30 Baltimore kétmotoros közepes bombázó amerikai tervezésű, de teljes egészében Nagy-Britanniában gyártott repülőgép volt, amely 1942-ben állt szolgálatba. A legyártott 1.575 darab bombázóként és felderítőként is helytállt. Munson 1995, 298-299.

123 AN 72 AJ 239. Bombardement à la carte (5), 15.

124 AN 72 AJ 239. Note sur le groupe Lorraine et sur le lieutenant-colonel Lionel de Marmier, 8-9. 125 Pernot, 1990. 15.

126Broche-Caïtucoli-Muracciole 2007, 350.

127 AN 72 AJ 239. Les Forces Aériennes Françaises Libres 1940-1942, 2. 


\section{Felhasznált irodalom}

\section{Levéltári források:}

Archives nationales:

- 72 AJ 220. Chronologies de la France libre et de la France combattante.

- 72 AJ 239. Forces aériennes françaises libres (FAFL).

Service Historique de Défense:

- AC 21 P. Division des Archives des Victimes des Conflits Contemporains.

Könyvek:

- Broche, François (2002): L'Armée française sous l'Occupation. La métamorphose. Paris, Presses de la Cité.

- Broche, François - Caïtucoli, Georges - Muracciole, Jean-François (2007): La France au combat de l'Appel du 18 juin à la victoire. Paris, Perrin.

- Broche, François - Muracciole, Jean-François (szerk.) (2010): Dictionnaire de la France libre. Paris, Robert Laffont.

- Chaline, Emile - Santarelli, Pierre (1989): Historique des Forces navales françaises libres. Paris, Service Historique de la Marine.

- Clostermann, Pierre (1948): Le grand cirque. Paris, Flammarion.

- Facon, Patrick (2005): L'armée de l'air dans la tourmente. La bataille de France 1939-1940. Paris, Economica.

- Lormier, Dominique (2006): C'est nous les Africains. L'épopée de l'armée française d'Afrique 1940-1945. h. n., Calmann-Lévy.

- Munson, Kenneth (1995): A II. világháború repülőgépei. A hadviselő felek valamennyi repülőgépe. Budapest, Müszzaki Könyvkiadó.

- Trouplin, Vladimir (2010): Dictionnaire des compagnons de la Libération. Bordeaux, Elytis.

- Vincent, Jean-Noël (1983): Les Forces françaises dans la lutte contre l'Axe en Afrique. Les Forces françaises libres en Afrique 1940-1943. Paris, Ministère de la Défense.

\section{Folyóiratban megjelent tanulmányok:}

- Ballatore, André (1989): „« Dès la capitulation, j’avais pris ma décision »”. Icare, 128. sz. 68-75. pp.

- Bauden, René (1989): „En Lybie avec les Blenheim à l'assaut de l'Afrika Korps”. Icare, 128. sz. 120-123. pp.

- Boisot, Marcel (1990): „Quelques souvenirs intenses”. Icare, 136. sz. 68-73. pp.

- Buffotot, Patrice (1980): „Les forces aériennes françaises libres en Afrique; l'escadrille „Topic” du G.R.B.1 à Koufra en février 1941". Revue historique des armées, 139. sz. 171-188. pp.

- Charles, R. (1964): „Les Forces aériennes françaises libres en Afrique”. Revue historique des armées, 77. sz. 101-126. pp.

- Charrasse, André (1990): „La France libre au Moyen-Orient: Une aventure”. Icare, 136. sz. 74-79. pp.

- Cunibil, Robert (1989): „L'épopée du Free French Flight no 1 dans la campagne d'Abyssinie”. Icare, 128. sz. 82-93. pp.

- Delpech, Jean (1989): „Tulasne m’a dit : « demain matin, tu pars pour Ismaïlia »”. Icare, 128. sz. 112-119. pp.

- Denis, James (1989): „De La Rochelle à Tobrouk: quelle aventure!” Icare, 128. sz. 44-53. pp.

- Donjon, Yves (2002): „Le Groupe de bombardement „Lorraine””. Espoir, 129. sz. 53-57. pp.

- Dupérier, Bernard (1990): „Le 242, le 615 et les débuts du groupe « Ile-de-France »”. Icare, 133. sz. 48-77. pp.

- Ezanno, Yves (1990): „Libye 1942: La retraite”. Icare, 136. sz. 30-37. pp.

- Geiger, Raymond (1989): „« Nous n'avons pas accepté l'armistice»”. Icare, 128. sz. 94-109. pp.

- Giocanti, François (1990): ,Je me suis évade de Djibouti...” Icare, 136. sz. 80-83. pp.

- Jacquier, Paul (1989): „Juin 1940: les débuts de l'aviation de la France Libre au MoyenOrient”. Icare, 128. sz. 34-43. pp. 
- Jaeger, Charles (1990): „Le long chemin”. Icare, 136. sz. 100-110. pp.

- Lafont, Henry (1989):" Chronologie des Forces aériennes françaises libres au Moyen-Orient du 18 juin 1940 à la naissance du groupe «Alsace »". Icare, 128. sz. 8-29. pp.

- Lafont, Henry (1990): „De l'Angleterre au Western Desert”. Icare, 136. sz. 30-47. pp.

- Lafont, Henry (1990): „Les premiers chasseurs français en Angleterre”. Icare, 133. sz. 22-29. pp.

- Lorrain, Raymond (1990): ,Soixante-dix jours de bateau de Suez à Greenock”. Icare, 136. sz. 154-163. pp.

- Marchand, Alain (2002): „Les avions FAFL”. Espoir, 129. sz. 25-32. pp.

- Millet, Jérôme (1987): „Les Forces aériennes françaises libres au combat, au sud du Sahara, 1940-1942”. Revue historique des armées, 168. sz. 17-23. pp.

- Pange (de), Jean (1972): „Mon U-2 était la bonne à tout faire...” Icare, 62. sz. 154-161. pp.

- Perrot, François (1990): „Les F.A.F.L.: une étude de motivations”. Revue historique des armées, 179. sz. 114-123. pp.

- Pouliquen, Joseph (1990): „La formation du groupe « Alsace »”. Icare, 136. sz. 10-21. pp.

- Saint-Péreuse (de), Pierre Tassin (2002): „Le groupe « Bretagne»”. Espoir, 129. sz. 95-101. pp.

- Raoul-Duval, Claude (1990): „Au jour le jour, la campagne du groupe « Alsace »”. Icare, 136. sz. 38-67. pp.

\section{szerzőröl}

PhD habil.,

egyetemi docens,

tanszékvezetō

PTE BTK

Romanisztika Intézet

Francia Tanszék

About the Author

PhD, Associate Professor,

Head of Department

Department of French,

Faculty of Humanties,

University of Pécs

(1)

benekrisztian@yahoo.fr

\section{English Abstract}

\section{The Activity of the Free French Air Forces in Africa}

The Free French Air Forces were the air branch of the Free French Forces during the Second World War from 1940 to 1943 when they finally became part of the new regular French Air Forces. This study aims to present the activity of this special and little-known air force over the territory of Africa during this period.

After the French defeat in June 1940 General Charles de Gaulle went to England to continue the fight against the Axis Forces and created the Free French Forces. Several airmen of the French Air Forces rallied to General de Gaulle which allowed the creation of the Free French Forces on 1st July 1940 under the command of Admiral Émile Muselier. The Free French commandment wanted to deploy their units during the reconquest of the French African colonies, so they were sent to participate in the occupation of French Equatorial Africa in 1940. Other flying units struggled in East and North Africa together with British troops against the invading Italian armies. These forces were reorganized in 1941 and continued the fight in the frame of fighter and bombing squadrons (groupes in French). Most of them (five of seven) were created and deployed in Africa as the Lorraine, the Alsace, the Bretagne, the Artois and the Picardie squadrons.

From 1940 to 1943 5,000 men served in the ranks of the Free French Air Forces, which is a modest number if we compare with the power of the air forces of the other allied countries. At the same time, the presence and the activity of these forces were an important aid to Great Britain during a hard period of its history, so this contribution was appreciated by the British government in the end of the war at the political scene. 